Article

\title{
Glacial Geomorphology and Preliminary Glacier Reconstruction in the Jablanica Mountain, Macedonia, Central Balkan Peninsula
}

\author{
Marjan Temovski ${ }^{1,2, *}$, Balázs Madarász ${ }^{3}{ }^{(1)}$, Zoltán Kern ${ }^{1}{ }^{(\mathbb{D}}$, Ivica Milevski ${ }^{4}$ and \\ Zsófia Ruszkiczay-Rüdiger ${ }^{1, *}$ \\ 1 Institute for Geological and Geochemical Research, MTA, 1112 Budapest, Hungary; zoltan.kern@gmail.com \\ 2 Isotope Climatology and Environmental Research Centre, Institute for Nuclear Research, MTA, \\ 4026 Debrecen, Hungary \\ 3 Geographical Institute, MTA, 1112 Budapest, Hungary; madarasz.balazs@csfk.mta.hu \\ 4 Institute of Geography, Faculty of Natural Sciences and Mathematics, Ss. Cyril and Methodius University, \\ 1000 Skopje, Macedonia; ivicamilevski@gmail.com \\ * Correspondence: temovski.marjan@atomki.mta.hu (M.T.); rrzsofi@geochem.hu (Z.R.-R.)
}

Received: 20 June 2018; Accepted: 17 July 2018; Published: 23 July 2018

check for updates

\begin{abstract}
Although glacial landforms on the Balkan Peninsula have been studied since the 19th century, only scarce data are available about the extent of the former glaciations in the Central Balkan Peninsula, the transition zone between the Mediterranean and Central Europe. Glacial features of the Jablanica Mt. were mapped, described and classified into morphostratigraphic units. A revised glacio-geomorphological map was produced and glacial landforms were assigned to six morphostratigraphic units. Ten primary and two secondary cirques were identified in the upper parts of the studied valleys, while downstream the valleys were steep and glacially shaped with several glacial steps and thresholds. Cirque and valley morphology indicate that subglacial deepening was limited within the cirques and was more intensive in the valley sections during more extensive glacial phases. The largest reconstructed glaciers were $4.6-7 \mathrm{~km}$ long, while the last cirque glaciers were only a few hundred meters long. Using morphostratigraphic data, a glacier reconstruction was carried out for the largest mapped glacial extent. On the basis of glacial geomorphology, a former equilibrium-line altitude (ELA) of $\sim 1800 \mathrm{~m}$ and glacier cover of $22.6 \mathrm{~km}^{2}$ were estimated during this stage. The local ELA values were compared to the regional ELA record and enabled to tentatively attribute a MIS 6 age for the reconstructed maximum ice extent in the study area.
\end{abstract}

Keywords: glacial geomorphology; glacial reconstruction; Jablanica Mt.; Quaternary; equilibrium line altitude; cirque morphometry; Macedonia

\section{Introduction}

Glacier reconstruction enables the calculation of palaeoglaciological and palaeoclimatic variables [1]. Such data are important for our understanding of past atmosphere-cryosphere interactions [2] and can serve as constraining boundaries for palaeoclimate models. However, in order to reach these goals, reconstruction of palaeoglaciers on the basis of the glacial landforms is essential [3].

Glacial landforms of the Balkan Peninsula have been studied since the late 19th century [4-7]. Several lines of evidence suggest extensive past glaciations of the coastal ranges of the Adriatic Sea in the form of ice caps and valley glaciers [8]. However, scarce data are available about the extent of the glaciations in the Central Balkan Peninsula. 
The description of the glacier extent during past glaciations was completed by age determination of glacial landforms in Montenegro and northern Greece using U-series techniques [9-13], with the results suggesting repeated glaciations during at least three separate cold stages, the oldest of which occurred earlier than $350 \mathrm{ka}$. These glaciations were correlated with the MIS 12, MIS 6 and MIS 5d-2 cold stages, with the most extended glaciation during the oldest phase. At other locations surface exposure dating using cosmogenic radionuclides (SED) of moraines was used to estimate the age of glacial stages. In the Šar and Pelister Mountains of Macedonia and in the Rila Mts. (Bulgaria) preliminary ${ }^{10} \mathrm{Be}$ SED ages were obtained [14-16]; and ${ }^{36} \mathrm{Cl}$ SED dating was recently applied in the Greece $[17,18]$ and southern Macedonia (Galičica Mountain) [19]. Other than Mt. Chelmos in Southern Greece [18], no evidence of a glaciation older than the Last Glacial Maximum (LGM, MIS 2) was described by these studies. Extended ice caps were also reported in the coastal ranges of northern and central Croatia, with glaciers extending down to or possibly the present-day sea level [20,21], however no numerical age control is available.

During the Holocene most of the mountains on the Balkan Peninsula were unglaciated. Today only some small (and rapidly shrinking) glaciers or permanent snow patches above $2000 \mathrm{~m}$ elevation a.s.l. exist in the region [22]. Their mass balance heavily depends on topoclimatic factors, such as receiving extra snow by avalanching and wind drift, and being shaded by steep cirque-walls [23].

The reconstructed equilibrium-line altitudes (ELAs) for the most extended glacial phase in the coastal range are under $1300 \mathrm{~m}$ (the lowest in the Mediterranean), and its elevation manifests a rapid increase inland with values around $1800-2200 \mathrm{~m}$ in the Central Balkan Peninsula [2,8,14]. However, this pattern is ambiguous because glaciers reached their maximum extent asynchronously between MIS 12 and MIS 2. The apparently extensive ice caps in the coastal ranges along the Adriatic Sea and more limited extent of inland glaciations suggest that the coastal ranges with large icefields blocked the inland penetration of humid air masses from south to north, resulting in much drier conditions in the Balkan interior and in the Pannonian Basin compared to the coastal margin of the Balkan Peninsula [10].

Despite the large number of studies devoted to the glaciations of the mountains of the Balkan Peninsula, information on the glacial history of the transitional areas between the coastal ranges and the inland areas is limited. There are many unresolved or contradictory issues regarding the glacial chronology of the Central Balkan Peninsula due to the scarcity of chronological data. This study focused on glacier reconstruction-based on detailed glacial geomorphology of the area-and assessment of the former ELAs of the Jablanica Mt. The mapped glacial landforms will provide the necessary stepping stone towards a future geochronological study [24].

\section{Study Area}

\subsection{Location and Geological Setting of the Jablanica Mountain}

The Jablanica Mountain is a $45 \mathrm{~km}$ long, $25 \mathrm{~km}$ wide and NNW-SSE oriented mountain range, part of the Dinaride-Hellenide mountain belt, located in the central part of the Balkan Peninsula, along the border between Albania and Macedonia [25] (Figure 1A).

Morphologically, the range is divided in three parts (Figure 1B). The southern part (between the Mokra Mt. (Albania) to the south and the Belica Valley), is mostly plateau-like with karstic landscapes culminating at Čumin Vrv (2125 m).

The middle part (between the Belica and Piskupština Valleys) is the highest part of the mountain (highest peaks: Crn Kamen, 2257; Strižak, 2233) with a glacially sculptured plateau-like crest [25]. This study focused on this part of the mountain, comprising the valleys of Vevčani, Podgorci and Labuništa-Pupuljak (Figure 1B). These valleys strike from west to east draining to the Black Drin (Crn Drim) river.

The northern part (from the Piskupština Valley to the Debar Basin) has generally lower elevation (highest peaks: Raduč, 2083; Strmnica, 1904) (Figure 1B). 


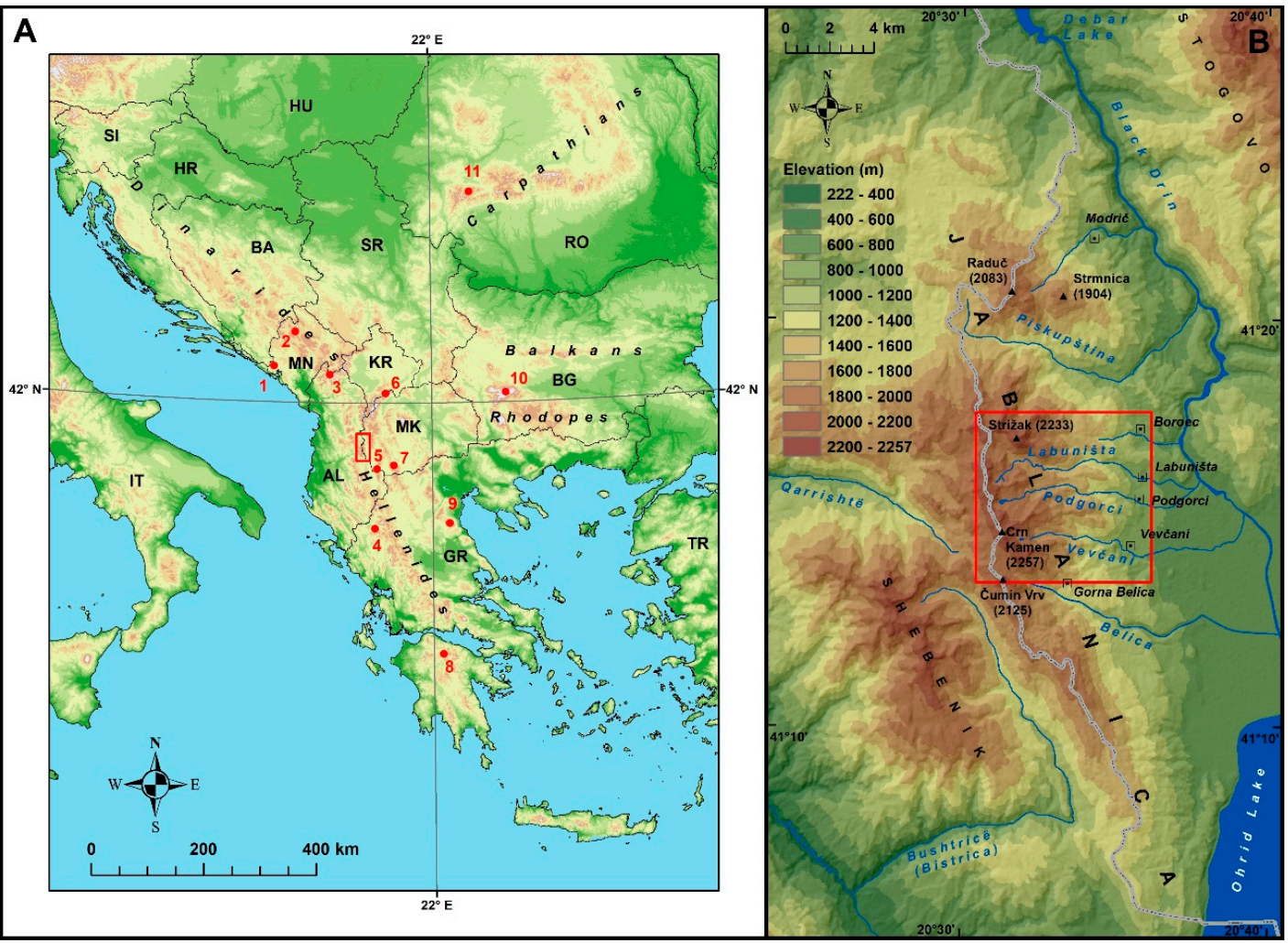

Figure 1. Location of Jablanica Mountain in the Balkan Peninsula (A) and a closer look at the general morphology of the mountain (B) with red rectangle showing the study area. Mountain ranges mentioned in text are shown by numbers: 1-Orjen Mt., 2-Durmitor Mt., 3-Prokletije Mts., 4-Pindus Mts., 5-Galičica Mt., 6-Šar Mts., 7-Pelister Mt., 8-Chelmos Mt., 9-Mt. Olympus, 10-Rila Mts., 11-Retezat Mts.

The folded structure of the Jablanica Mt. (mostly N-S- to NW-SE-oriented larger synclines and anticlines) has been cut by several normal faults during the Neogene extension affecting this part of the Balkan Peninsula [26]. On the east it is bounded by Neogene sedimentary basins and by the Shebenik Mt. on the west. [25]. The basins were initiated during the Late Miocene along a NNW-oriented fault line, as part of the South Balkan Extensional System [26,27], and were filled with lacustrine deposits of Upper Miocene, Pliocene and Quaternary age. The Ohrid graben is still actively developing, hosting the $285 \mathrm{~m}$ deep Ohrid Lake [28]. The Jablanica Mt. has uplifted at the footwall of the normal faults bounding the subsiding grabens to the east, with most likely faster uplift during the Pleistocene [29].

The Jablanica Mt. is mostly composed of Triassic sediments overlying Paleozoic (Devonian) metamorphic rocks and is partly covered by Jurassic sediments. These rocks were intruded by Jurassic mafic-ultramafic magmatic rocks. The eastern and northeastern foothills are covered by Neogene lacustrine sediments [30] (Figure 2).

The study area, the middle part of the Jablanica Mt., is almost entirely composed of Triassic rocks, with the underlying Paleozoic schist only partly exposed at lower elevations. The stratigraphically lower part of the Triassic section is built of clastic sediments (sandstone and shale), covered by a thick carbonate section, composed of massive to platy and cherty limestone and dolomite. The mountain crest in the study area is almost entirely built of Jurassic conglomerate. This formation is composed of fragments of the Jurassic magmatic and the Triassic clastic and carbonate formations and it is cut by a number of quartz veins [30]. 


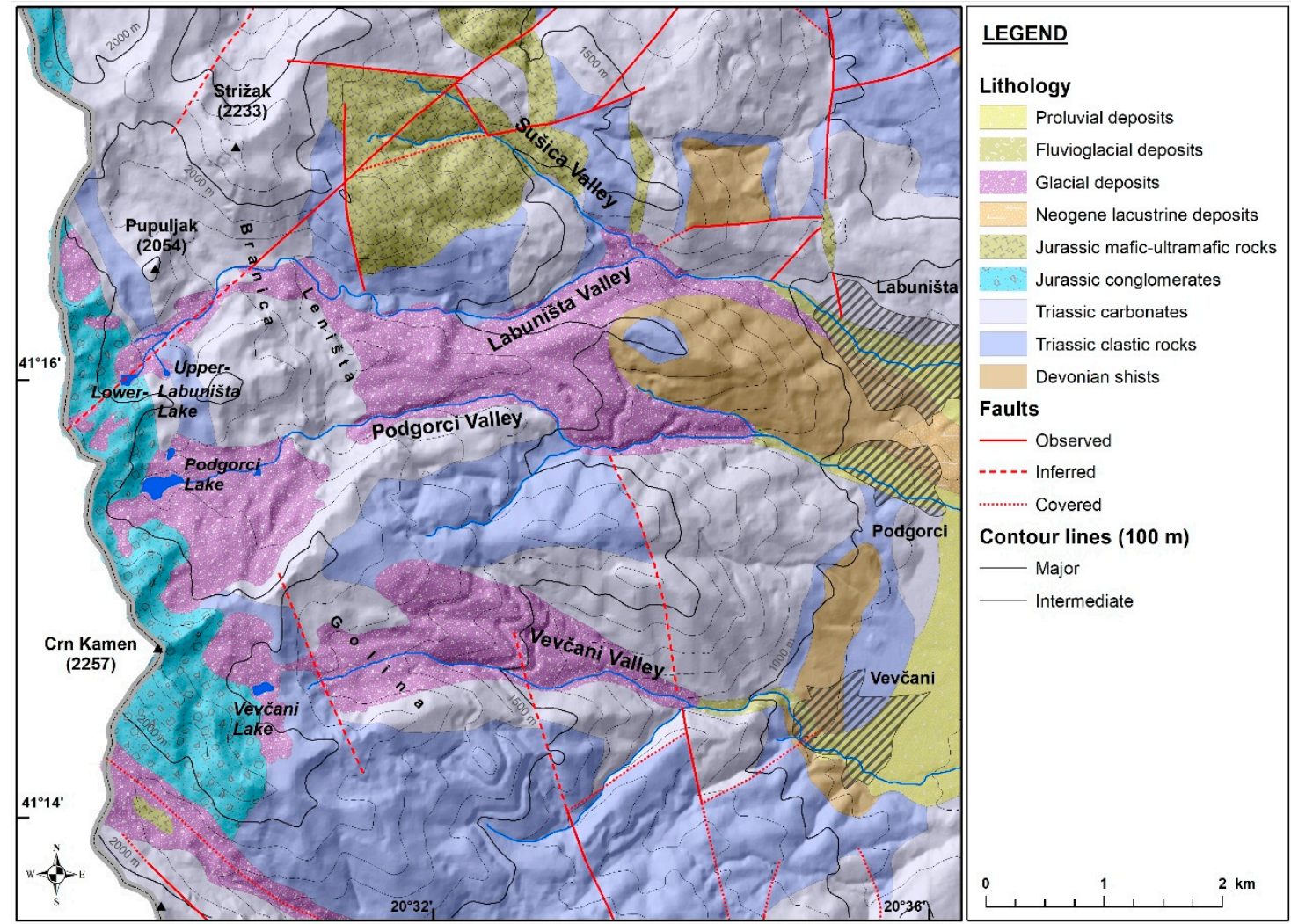

Figure 2. General geological map of the study area on Jablanica Mountain.

\subsection{Introduction to the Glacial Geomorphology of the Study Area and Previous Results}

Currently, neither glaciers nor permanent firn patches can be found on the Jablanica Mt., however geomorphological evidence of past glaciation is abundant [25,31,32].

The first evidence of former glaciation on the Jablanica Mt. was presented by Dedijer [6]. He visited the area north of the Belica Valley, and described the largest cirques with a system of glacial valleys and the development of stepped cirques. He noted the lack of cirques in the Belica Valley (Figure 1B), although it has a clear glacial morphology. He noted a number of cirques in the upper parts of Labuništa, Podgorci and Vevčani valleys, as well as the extensive moraine deposits with large boulders between the Labuništa and Podgorci rivers. In the northern area, a less-developed glacial morphology was described. He reported the lowest moraines at an elevation of $750 \mathrm{~m}$ a.s.l. in the north (near Modrič village; Figure 1B), and near or below the villages of Vevčani, Podgorci and Labuništa (850-900 m) in the central part of the range, and suggested two glaciations in the area. In addition, Cvijić [5] described a possible terminal moraine even lower, at $700 \mathrm{~m}$ elevation, to the north of Labuništa village, at the confluence of Borovec River and the Black Drin (Figure 1B).

Kolčakovski [25] focused on the glacial and periglacial processes and forms of the Jablanica Mt. He worked generally in the upper parts (above $1500 \mathrm{~m}$ ). He considered the sediments below $\sim 1700 \mathrm{~m}$ as fluvioglacial and, thus did not discuss the glacial deposits previously reported at lower elevations. According to his observations the largest glacier that occupied the Labuništa-Pupuljak valley system descended towards a terminal moraine at $1732 \mathrm{~m}$ (Branica locality; Figure 2). Therefore, the age of this glacial extent was assigned to the LGM with an estimated ELA of $1964 \mathrm{~m}$. For Podgorci and Vevčani valleys he suggested that the most extensive glaciers reached an elevation of 1600-1700 m a.s.l. 


\subsection{The Climate of the Jablanica Mountain}

The climate of the Jablanica Mt. is strongly influenced by the nearby Ohrid Lake and the Adriatic Sea, which is located only $80 \mathrm{~km}$ to the west (Figure 1A). The Ohrid Lake has more influence on the temperature regime than the Adriatic Sea, with the latter having higher effect on the precipitation of the study area. According to the WorldClim v2 model [33] and MODIS data [34], the highest parts of the mountain (above $1800 \mathrm{~m}$ ) have mean annual temperatures between $3-4{ }^{\circ} \mathrm{C}$, while toward the foothills, mean annual temperatures increase to $10-11^{\circ} \mathrm{C}$. The mean summer temperatures (July, August, September) are between $12{ }^{\circ} \mathrm{C}$ at the highest elevations, to $2{ }^{\circ} \mathrm{C}$ at the mountain foot. The mean January temperatures fall in the range of $-5^{\circ} \mathrm{C}$ at the highest elevations, to $1.5^{\circ} \mathrm{C}$ in the foothills. Based on this temperature range, the local lapse rate is calculated to $0.58^{\circ} \mathrm{C} / 100 \mathrm{~m}$.

According to the WorldClim v2 model, the mean annual precipitation increases from $800 \mathrm{~mm}$ at the mountain foot to $1150 \mathrm{~mm}$ at the highest parts (above $1800 \mathrm{~m}$ ). The precipitation regime is Mediterranean, with the greatest amount of precipitation falling during the winter, and lowest during the summer. The mean monthly precipitation in January is about $100-110 \mathrm{~mm}$ in the highest part to $80 \mathrm{~mm}$ in the bottom, whereas mean August precipitation is only half of that: $50-60 \mathrm{~mm}$ at the top, to $40-45 \mathrm{~mm}$ at the foothill of the mountain. Winter precipitation is mostly snow, especially in the higher parts of the mountain. Thus, according to the MODIS data, average snow cover in the highest part is about 5 months, i.e., from November to April and the snow depth can be significant-up to $2 \mathrm{~m}$.

\section{Methodology}

\subsection{Geomorphological Mapping}

Geomorphological mapping was conducted on the basis of field investigations and combination of available data sources: topographic maps at 1:25,000 scale [35], a basic geological map in 1:100,000 scale [30], GoogleEarth images at varying scales, and a 9-m resolution digital elevation model (DEM). The DEM was generated from the 5-m (2009) and from the 20-m (2005) DEM model of the Agency for Real Estate and Cadastre of the Republic of Macedonia [36].

For cirque and cirque-floor delineation a combination of field identification, topographic maps, and DEM-derived contour and slope maps was utilized [37]. In the field a number of ground control points were collected using a hand-held GPS as a reference for the mapped geomorphological features. Digital cartographic work, morphometric analyses and final map production were done using Global Mapper (v17, Blue Marble Geographics, Hallowell, ME, USA) and ArcGIS (v10.1, ESRI, Redlands, CA, USA) software.

Moraines were classified into morphostratigraphic units [38] based on their elevation, relative position and field observations on their preservation state (e.g., degree of erosion).

Because the study area comprises nearby valleys of similar aspect and elevation range, they are expected to have shared a similar ELA during the same glacial phase. Therefore, ELA estimates of the reconstructed glaciers (see Section 3.3) were used to verify the preliminary morphostratigraphic classification of the studied landforms.

Basic cirque morphometric parameters were derived from the 9-m DEM using the previously delineated cirque boundaries in ArcGIS v10.1 and Global Mapper v17. Cirque aspect is given as median axis aspect, cirque length (L) as the length of the median axis, cirque width (W) as the longest line perpendicular to the median axis, cirque height $(\mathrm{H})$ as the vertical distance between the lowest and highest point within the cirque boundaries, cirque size as the cube root of volume $(\sqrt[3]{\mathrm{L} \times \mathrm{W} \times \mathrm{H}})$, and cirque floor altitude as the modal floor altitude [37]. We also measured cirque profile closure (taken as maximum slope of the headwall) and plan closure [39] and calculated the exponents for logarithmic (power) regressions of the size parameters (length, width, height) on overall cirque size to check for allometric development of the cirques [40]. Based on their morphological and morphometric characteristics we attempted to classify the identified glacial cirques according to the classification system of Evans and Cox [41]. 


\subsection{Glacier Reconstruction}

Glacier reconstruction was based on the position of the landforms of glacial accumulation (lateral and terminal moraines) and erosion (U-shaped valleys, trimlines, glacially sculpted bedrock, glacial steps and over deepened valley sections). Furthermore, where the position of former moraines was inferred from a combination of topographic features (like change of valley slope, narrowing valley section with incised creek, scattered erratic boulders) allowing glacier terminations to be tentatively mapped in places where terminal moraines have been removed by erosion. The reconstructed glaciers were created using the GlaRe (Glacier Reconstruction) ArcGIS toolbox [42] using the 9-m DEM. The GlaRe toolbox offers a semi-automated method of glacier reconstruction. It generates the ice thickness from bed topography along a user defined flowline. It applies the physical laws for ice flow to generate a 3D palaeoglacier surface using several interpolation methods. As the modern land surface differs from the concurrent land surface below the glacier, the postglacial incision or sedimentation will make the reconstructed glacier thicker or thinner, respectively.

The ice thickness was adjusted to the mapped glacial landforms by increasing or decreasing the basal shear stress value $(\tau b)$ as this is a first-order control on the output glacier surface. The ice thickness is calculated by the software along the flowline using a user defined basal shear stress value (Flowline ice thickness tool). Then the glacier surface was created by the Glacier surface interpolation tool, applying the "Topo to raster" setting.

The most accepted values of the basal shear stress vary within the $\sim 50-150 \mathrm{kPa}$ range with possible increase to $190 \mathrm{kPa}$ [43-45]. The $\tau \mathrm{b}$ was iteratively tuned within this realistic range until the virtual palaeoglacier surface best matched the mapped glacial features of the topography. Although basal shear stress may vary under a real glacier, we used a uniform value of $\tau b$ for the preliminary modelling tests. The tests suggested no major change in the shape of the reconstructed glacier when this parameter was set to be variable along the glacier.

Where topography suggested glacier confluence, the present day topographic divides were set as ice divide. The elevation of the neighbouring glaciers could be adjusted by fine-tuning their thickness using the $\tau b$ value.

\subsection{Calculation of the Paleo-ELAs}

The equilibrium-line altitude (ELA) is the spatially averaged elevation of the points on the surface of the glacier where the climatic mass balance is zero [46]. It represents the lower boundary of annual snow accumulation. Accordingly, the ELA is characteristic of the prevailing climate conditions [47].

The palaeo-ELAs were estimated using the ELA Calculation toolbox [48]. For the calculations the Accumulation Area Ratio (AAR) method was used. The main input needed for calculation of the AAR is the reconstructed 3D glacier-surface, the creation of which was previously described (Section 3.2).

To consider the glacier geometry and hypsometry, the AAR values were selected depending on the glacier size. The relationship between the glacier area and the balanced-budget AAR can be optimally described by a logarithmic regression equation [49]:

$$
\operatorname{ssAAR}_{0}=0.0648 \times \ln (S)+0.483,
$$

where $\operatorname{ssAAR}_{0}$ is the size-specific balanced-budget AAR, and $S$ is the planimetric area of the reconstructed glacier $\left(\mathrm{km}^{2}\right)$

The palaeo-ELAs were also estimated by the Area-Altitude Balance Ratio (AABR) method. This method is frequently recognised as more robust (compared to the simple AAR) as it is based on the hypsometry of the former glacier and the ratio between the accumulation and ablation gradients [50,51]. Balance ratios vary with regional climate $(\sim 1$ in polar regions and $\sim 2$ in tropical regions). The regional AABR of 1.6, calculated from the contemporary glaciers of the European Alps [52], was assumed as potentially representative for the glaciated Jablanica Mt. and used in the current study. The palaeo-ELAs estimated by both methods enable regional comparisons with other 
studies using the AAR or the AABR method for ELA calculations. Besides, it gives the opportunity to compare the results provided by the two methods, to assess uncertainties of ELA estimates.

\section{Results}

The studied valleys have well developed glacial cirques at their heads along the mountain crest. Cirque floors of all valleys, except for the Pupuljak Valley, host glacial lakes, such as Vevčani Lake located at 1955 m, Podgorci Lake at 1894 m, and Upper and Lower Labuništa Lakes located at 1918 and $1913 \mathrm{~m}$, respectively. Glacially sculptured landscapes are well preserved in the upper parts of the valleys with glacial sediments (i.e., till) found down to elevations of approx. $1000 \mathrm{~m}$ (Figure 3).



Figure 3. Glacial geomorphological map of the middle part of Jablanica Mountain. Blue numbers indicate the locations of the photos on Figures 4 and 5.

\subsection{Glacial Morphology and Deposits}

The valley heads of the studied glacially sculptured valleys (Vevčani, Podgorci, and Labuništa valleys) form simple and compound glacial cirques along the mountain crest (Figures 3 and 5; see more in Section 4.2). Although affected by later slope erosion and post-glacial valley incision, these valleys exhibit a wide, U-shaped morphology narrowing downstream. It is an open question whether the glaciers extended to the foothills during their most extended phases, as it was suggested by Cvijić [5], or terminated as valley glaciers at or above the mountain front (Figure 3). Presently, no evidence of glaciers reaching 700-750 m elevation along the foothills could be found, but the possibility of former piedmont glaciers cannot be excluded. 


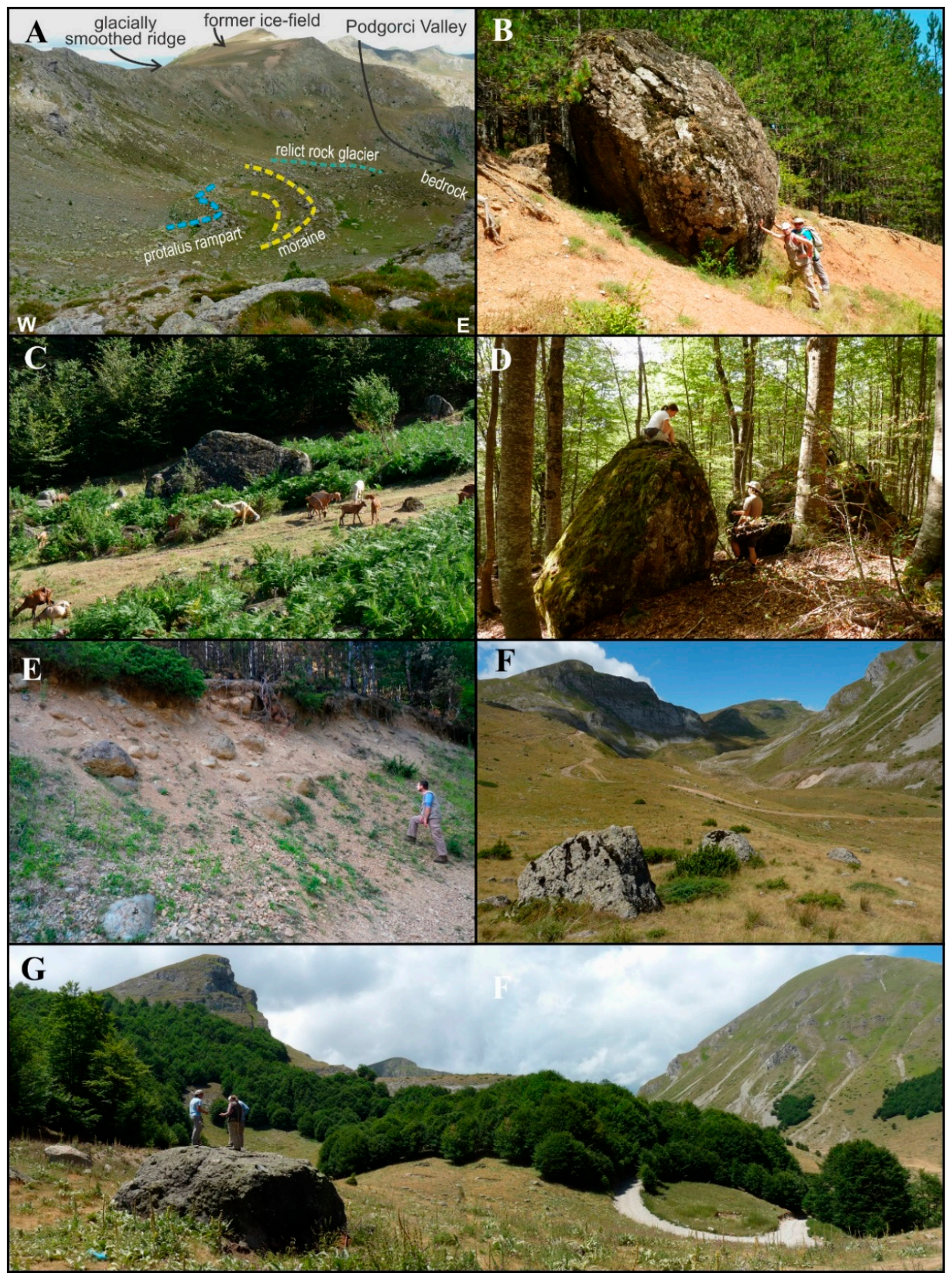

Figure 4. Glacial morphology and deposits on Jablanica Mountain. (A) The uppermost part of Podgorci Valley having ridges with glacially smoothed morphology; Large glacially transported boulders of Jurassic conglomerate (Vevčani Member) in the lower parts of Vevčani (B) and Podgorci (C) valleys; (D) Large boulders of Jurassic conglomerate in the middle part of Vevčani Valley (Kutel Member); (E) Fluvioglacial deposits in the lower parts of Podgorci Valley; (F) Erratic boulder of Jurassic conglomerate (1.5 m high) laying on carbonate bedrock at Branica locality, with view of Pupuljak Valley in the back; (G) Large Jurassic conglomerate boulders of Leništa Member in Labuništa-Pupuljak Valley at Leništa locality. For location of the photos refer to Figure 3.

The main ridge reaches an elevation between 2000 and $2200 \mathrm{~m}$, and likely preserves a remnant of a Paleogene planation surface, which can be found on other mountains in Macedonia [29]. Several sections of the main ridge are smoothed, as well as multiple segments of the secondary 
ridges separating the cirques (Figure 4A). This morphology may reflect the former existence of a major interconnected icefield with limited number of unglaciated peaks (e.g., Crn Kamen, Pupuljak, Strižak).

Most of the valley floors are covered by glacial deposits, with creeks generally incised along the border of the glacial deposits and former glacial valley sides in the lower valleys (Figures 2 and 3 ). In the upper valley sections morphologically well expressed glacial steps have developed frequently at the contact of lithological boundaries and/or along tectonic structures (Figures 2, 3 and 5C).

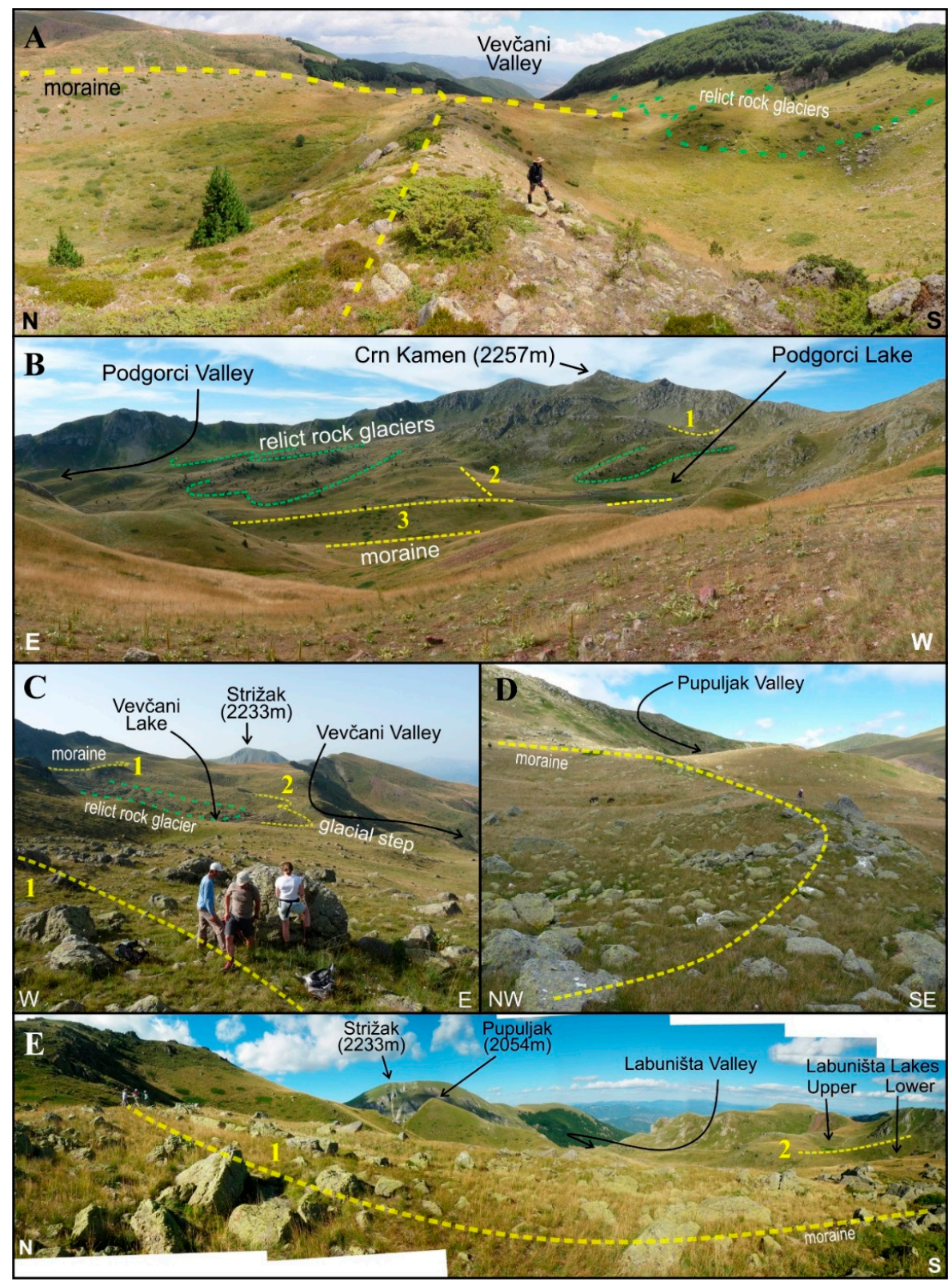

Figure 5. Characteristic glacial and periglacial features of the study area. (A) Moraines of Jurassic conglomerate (Golina Member) in the middle part of Vevčani Valley at Golina locality; (B) Several moraine generations (yellow dashed lines, Lincura (1), Golina (2) and Leništa (3) Members) and rock glaciers (reworked glacial sediments; green dashed lines) in the Upper Podgorci Valley; (C) Moraines from Lincura (1) and Lokva (2) Members and rock glaciers in the Upper Vevčani Valley; (D) Moraine of the smallest glacier (Lincura Member) in the Upper Pupuljak Valley; (E) Moraine of the Lincura Member in the Upper Labuništa Valley (1) and Lateral moraine belonging to the Golina Member in the Upper Podgorci Valley (2). For location of the photos refer to Figure 3. 
Glacial deposits (Jablanica Glacial Formation) are found throughout the study area, extending down to elevations of $\sim 1100 \mathrm{~m}$ at Vevčani and Podgorci valleys (Figure $4 \mathrm{~B}, \mathrm{C}$ ), and possibly to $\sim 950 \mathrm{~m}$ at Labuništa Valley. Boulders of 0.5 to $10 \mathrm{~m}$ in diameter are the most prominent features of the glacial sediments (Figures 4 and 5). The moraine boulders are mostly (90\%) composed of Jurassic conglomerate with smaller amount of Triassic sandstone, shale and limestone. The boulders composed of Jurassic conglomerate are best preserved, and because their source bedrock can only be found along the mountain crest (Figure 2), their presence downvalley was useful for the clear identification of glacial and fluvioglacial sediments. Based on the position of the glacial sediments the Jablanica Glacial Formation was classified in several members. These members are considered to belong to the same chronostratigraphic unit, based on their position, morphology and sediment properties [38]. The landforms are best preserved in the Vevčani Valley, therefore most of the type localities and stratigraphic names come from this valley.

The studied glacial valleys are open towards their foothills, with no characteristic glacier terminations. In the Vevčani and Podgorci valleys the presence of large subrounded boulders of Jurassic conglomerate, the Vevčani Member, marks the extent of the largest mapped glaciers. Identification of moraines in the middle and lower part of all valleys was challenging due their poor preservation and dense forest vegetation (Figure 4B-D). However, ridges containing large boulders of Jurassic conglomerate and characteristic changes of valley morphology served as the basis for the identification of the Kutel and Leništa members.

Glacial landforms were better visible on the mountain pastures, although postglacial (e.g., periglacial) modification hindered the identification of primary glacial landforms. Nonetheless, the Golina Member is typically represented by lateral moraines below and occasionally also above the glacial steps, around $\sim 1900-1700 \mathrm{~m}$ a.s.l. (Figures 3 and 5B,E).

The upper parts of all of the studied valleys are characterised by wide glacial cirques mostly with an upper and a lower moraine generation (Lokva and Lincura Members; Figure 5B-E).

\subsubsection{Vevčani Member}

Very large boulders of Jurassic conglomerate can be found in the lowest part of the Vevčani Valley, at the elevation of $\sim 1100 \mathrm{~m}$. The moraine ridge was crosscut by the creek, therefore a latero-terminal moraine was mapped based on the presence of large boulders (Figures 3 and $4 \mathrm{~B}$ ).

The lowest part of the Podgorci Valley, at the elevation of $\sim 1200 \mathrm{~m}$, has a large number of sizable Jurassic conglomerate boulders, but with no clear morphological expression of a moraine (Figure 4C). A blockfield with sub-rounded boulders may evidence fluvioglacial modification of a former moraine deposit, and finer (from cobbles to sand) fluvioglacial sediments were mapped further down (Figure 4E). The former glacier termination was therefore mapped at the down-valley end of the deposit of large sub-rounded boulders.

In the Labuništa Valley, again no clear expression of a terminal moraine could be found. The presumed termination of the glacier tongue was inferred from a slight narrowing and ( 10 $\mathrm{m}$ high) bulging of the valley floor. In the lower part, at the elevation of $\sim 1325 \mathrm{~m}$, there is a remnant of a left lateral, or mid moraine between the main valley and its northern tributary Sušica Valley, composed of huge ( $\sim 8 \mathrm{~m}$ high) boulders of Jurassic conglomerate, which can be attributed to this phase.

In the middle part of Podgorci and Labuništa valleys an extensive area of glacial deposits developed during this phase, with the current watershed divide located in the area covered by the glacial deposits. This area appears to represent confluence of glaciers in the middle parts of both valleys, which were separated by a large hill of Palaeozoic schists in their lower reach (Figures 2 and 3).

\subsubsection{Kutel Member}

In the Vevčani Valley two moraine crests with abundant large (up to $3 \mathrm{~m}$ high) boulders of Jurassic conglomerates were interpreted as lateral moraines (Figures 3 and 4D). In the Labuništa Valley this member is represented by the termination of a flat valley section followed downstream by a steeper 
and incised reach, interpreted as a moraine. In the Podgorci Valley glacial sediments are widespread in the valley but with no clear indication of a moraine. The position of the former glacier terminus was inferred by a slight ( 10 $\mathrm{m}$ high) bulging of the valley-floor covered by glacial sediments.

\subsubsection{Leništa Member}

The Leništa Member is situated in the middle reach of each valley. In the Vevčani Valley, upstream from the steeper, forested segment, a lateral moraine with an uncertain termination was mapped on the northern side of a gently dipping, wide valley section covered by glacial sediments (Golina; Figure 3).

Similarly, a lateral moraine on the northern side of the Podgorci Valley could be followed below a mid-valley glacial step, down to $\sim 1650 \mathrm{~m}$, where the former glacier terminus is denoted by the termination of the lateral moraine. Glacial sediments re-shaped by periglacial rock-glacier activity above the valley scarp at 1840-1830 m a.s.l. elevation may belong to this phase as well. An inner and an outer lateral moraine ridge were also described to the northeast of the Podgorci Lake, which may belong to this phase.

In the Labuništa Valley, the position of the Leništa Member is represented by the presence of large boulders of Jurassic conglomerate where a break in the valley slope and incision of the creek in glacial sediment was observed (Leništa location; Figures 3 and $4 \mathrm{G}$ ). This landform has been identified as a poorly preserved terminal moraine.

After the confluence of the Pupuljak and Labuništa valleys, Jurassic conglomerate boulders carried from the highest parts of Labuništa Valley were deposited as erratics on the limestone bedrock sill above the scarp (Branica locality, Figure 4F). Kolčakovski [25] described a terminal moraine at Branica. Most probably the widespread erratic boulders of Jurassic conglomerate occurring on the glacial threshold were mistaken for a moraine (Figure $4 \mathrm{~F}$ ).

\subsubsection{Golina Member}

On the above described gently dipping valley section (Golina) of the Vevčani Valley, downstream from the glacial step, a well preserved double crested latero-terminal moraine complex was mapped (Figures 3 and 5A). Along the southern valley side, the lateral moraines have been modified by a series of rock glaciers.

Cirque floors of the Podgorci and Labuništa-Pupuljak valleys are at lower elevations compared to the Vevčani Valley. Therefore, in these valleys glaciers had retreated to their cirques by this phase.

In the Podgorci Valley the sediments belonging to the Golina Member are present around Podgorci Lake. The end moraine to the east of the lake is not well expressed due to subsequent periglacial modification.

In the Labuništa-Pupuljak system, sediments of the Golina Member are present around Labuništa Lake, similarly to the Podgorci Valley.

The Pupuljak Valley, a northern tributary of the Labuništa Valley, is the only glacial valley that lacks glacial deposits, although it preserves a well-expressed U-shape morphology. It is almost entirely developed in highly fractured carbonate rocks, which is probably the reason for the poor preservation of glacial deposits. In the Sušica Valley the termination of this phase was outlined based on a faint morphological indication of a small (2 m high) arcuate ridge at the elevation of 1810-1900 m a.s.l.

\subsubsection{Lokva Member}

In the Vevčani Valley a rock glacier extends down to the northern side of Vevčani Lake. The lake is enclosed on the eastern side by a partly preserved double crested moraine at an elevation of $\sim 1975 \mathrm{~m}$, below which a glacial step can be seen. This moraine is attributed to the Lokva Member (Figures 3 and 5C).

In the Podgorci and Labuništa-Pupuljak valleys the presence of sediments belonging to the Lokva Member is uncertain. In the Podgorci Valley the rock glacier activity may have overwritten the 
previous glacier deposits (Figures 3 and 5B). Moreover, this section of the valleys is relatively steep, providing no space for the development of well-preserved moraines. Another possibility is that the shrinking glaciers were confined to the cirques in these valleys for longer time, while in the Vevčani Valley the glacier was forced back to the top of the scarp. The latero-terminal moraine to the north of the Lower Labuništa Lake may belong to this member.

\subsubsection{Lincura Member}

In the Vevčani Valley the highest moraines are found at the elevation of $2040 \mathrm{~m}$, with the best expressed moraine to the east of Crn Kamen (2257 m) (Figures 3 and 5C).

In the Podgorci Valley the highest moraines are at the elevation of 2020-2070 m (Figures 3 and $5 \mathrm{~B}$ ). They are least preserved in the southern cirque, where glacial deposits have been reworked by (up to $0.4 \mathrm{~km}^{2}$ ) large rock glaciers.

The upper part of the cirques in Labuništa Valley are developed in Jurassic conglomerate, with the highest moraine at the elevation of $2030 \mathrm{~m}$, attributed to the Lincura Member. Most of the Pupuljak Valley has been carved in carbonate rocks and glacial deposits are missing, except in the cirque to the west of the Pupuljak peak, where the bedrock is Jurassic conglomerate, and a moraine was deposited at $2035 \mathrm{~m}$ elevation (Figures 3 and 5D,E).

The elevation of the higher cirque in the Sušica Valley may suggest the survival of a small glacier until this phase, but without clear morphological or sedimentological indications of its termination.

\subsection{Cirque Morphometry}

Ten primary cirques with two secondary cirques were identified in the upper parts of the studied valleys, forming compound cirques (Figure 6). The average elevation of the main cirques ranges from $1929 \mathrm{~m}$ to $2078 \mathrm{~m}$, with their total area between $0.3 \mathrm{~km}^{2}$ and $0.9 \mathrm{~km}^{2}$. Cirque floor elevations are between $1838 \mathrm{~m}$ and $1995 \mathrm{~m}$, and cirque floor areas between $0.03 \mathrm{~km}^{2}$ and $0.36 \mathrm{~km}^{2}$. The cirques are from $218 \mathrm{~m}$ to $399 \mathrm{~m}$ high, and from $598 \mathrm{~m}$ to $1029 \mathrm{~m}$ long. Most of them have an eastern and north-eastern (median axis) aspect, but two have southern and south-eastern aspect (Figure 7A). The two secondary cirques are smaller in all sizes, with cirque floors at similar elevations (2035-2051 m), cirque floor areas of $0.02 \mathrm{~km}^{2}$ and $0.09 \mathrm{~km}^{2}$, and are oriented to the north and east.

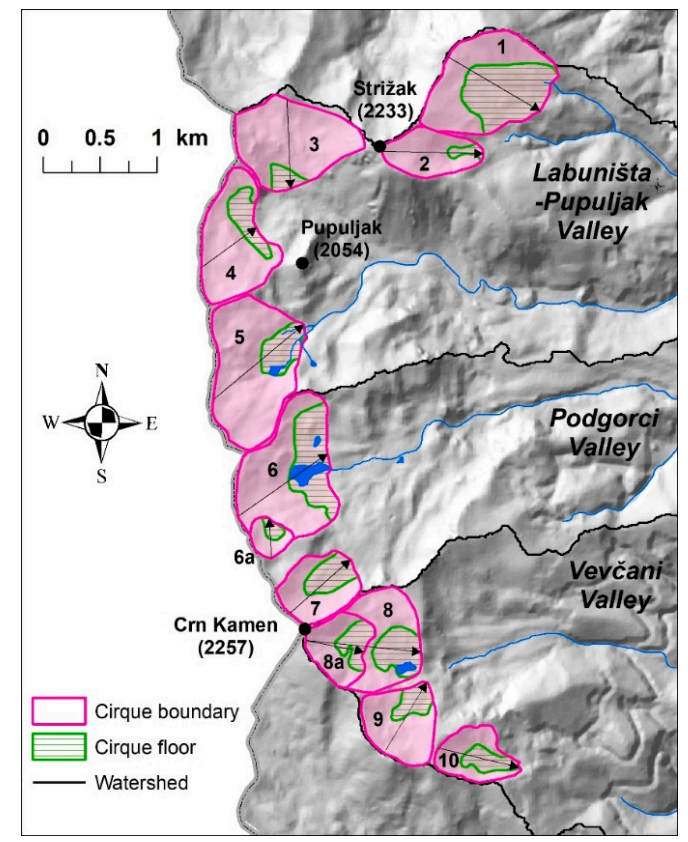

Figure 6. Cirques boundaries and cirque floors mapped in the studied area. 
Table 1. General morphometric characteristics of the glacial cirques. Grade system according to [41], with grade 3 representing a "definite" cirque and grade 4 a "poor" cirque.

\begin{tabular}{|c|c|c|c|c|c|c|c|c|c|c|c|c|c|c|c|c|}
\hline \multirow{2}{*}{\multicolumn{2}{|c|}{$\begin{array}{l}\text { Valley } \\
\text { Cirque }\end{array}$}} & \multicolumn{5}{|c|}{ Labuništa-Pupuljak Valley } & \multicolumn{3}{|c|}{ Podgorci Valley } & \multicolumn{4}{|c|}{ Vevčani Valley } & \multicolumn{3}{|c|}{ Summary } \\
\hline & & 1 & 2 & 3 & 4 & 5 & 6 & $6 a$ & 7 & 8 & $8 a$ & 9 & 10 & Min & Mean & $\operatorname{Max}$ \\
\hline \multirow{13}{*}{ 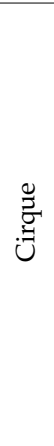 } & Min. elev. (m) & 1772 & 1892 & 1849 & 1911 & 1881 & 1893 & 2021 & 1985 & 1955 & 2025 & 1961 & 1851 & 1772 & 1916 & 2025 \\
\hline & Max. elev. (m) & 2171 & 2217 & 2196 & 2155 & 2157 & 2184 & 2189 & 2250 & 2242 & 2243 & 2179 & 2083 & 2083 & 2189 & 2250 \\
\hline & Mean elev. (m) & 1929 & 2057 & 1993 & 2004 & 2018 & 1984 & 2080 & 2078 & 2050 & 2099 & 2062 & 1947 & 1929 & 2025 & 2099 \\
\hline & Area $\left(\mathrm{km}^{2}\right)$ & 0.77 & 0.27 & 0.63 & 0.53 & 0.81 & 0.85 & 0.09 & 0.33 & 0.68 & 0.27 & 0.36 & 0.25 & 0.09 & 0.49 & 0.85 \\
\hline & Aspect $\left({ }^{\circ}\right)$ & 120 (SE) & $91(\mathrm{E})$ & $177(\mathrm{~S})$ & $53(\mathrm{NE})$ & $50(\mathrm{NE})$ & $55(\mathrm{NE})$ & $356(\mathrm{~N})$ & $48(\mathrm{NE})$ & $95(\mathrm{E})$ & $101(\mathrm{E})$ & $31(\mathrm{NE})$ & $103(\mathrm{E})$ & 31 & 107 & 356 \\
\hline & Length (m) & 936 & 883 & 785 & 598 & 1029 & 960 & 348 & 711 & 1014 & 518 & 727 & 738 & 348 & 771 & 1029 \\
\hline & Width (m) & 1026 & 451 & 1112 & 834 & 995 & 912 & 377 & 569 & 921 & 632 & 726 & 513 & 377 & 756 & 1112 \\
\hline & Height (m) & 399 & 325 & 347 & 244 & 276 & 291 & 168 & 265 & 287 & 218 & 218 & 232 & 168 & 273 & 399 \\
\hline & Size $(\sqrt[3]{\mathrm{L} \times \mathrm{W} \times \mathrm{H}})$ & 806 & 506 & 672 & 495 & 656 & 634 & 280 & 475 & 645 & 415 & 486 & 444 & 280 & 543 & 806 \\
\hline & $\mathrm{L} / \mathrm{W}$ & 0.9 & 2.0 & 0.7 & 0.7 & 1.0 & 1.1 & 0.9 & 1.2 & 1.1 & 0.8 & 1.0 & 1.4 & 0.7 & 1.1 & 2.0 \\
\hline & $\mathrm{L} / \mathrm{H}$ & 2.3 & 2.7 & 2.3 & 2.4 & 3.7 & 3.3 & 2.1 & 2.7 & 3.5 & 2.4 & 3.3 & 3.2 & 2.1 & 2.8 & 3.7 \\
\hline & $\mathrm{W} / \mathrm{H}$ & 2.6 & 1.4 & 3.2 & 3.4 & 3.6 & 3.1 & 2.2 & 2.1 & 3.2 & 2.9 & 3.3 & 2.2 & 1.4 & 2.8 & 3.6 \\
\hline & Plan closure $\left({ }^{\circ}\right)$ & 294 & 259 & 188 & 236 & 174 & 275 & 272 & 192 & 281 & 246 & 247 & 261 & 174 & 244 & 294 \\
\hline \multirow{4}{*}{ 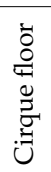 } & Floor area $\left(\mathrm{km}^{2}\right)$ & 0.36 & 0.03 & 0.05 & 0.10 & 0.12 & 0.27 & 0.02 & 0.11 & 0.14 & 0.09 & 0.17 & 0.07 & 0.02 & 0.13 & 0.36 \\
\hline & Floor elev. (m a.s.l.) & 1838 & 1906 & 1870 & 1930 & 1913 & 1893 & 2051 & 1988 & 1955 & 2035 & 1995 & 1875 & 1838 & 1937 & 2051 \\
\hline & Floor mean slope $\left(^{\circ}\right)$ & 15.0 & 16.2 & 10.3 & 10.3 & 11.1 & 10.2 & 11.9 & 11.9 & 10.6 & 10.4 & 12.7 & 12.9 & 10.2 & 12.0 & 16.2 \\
\hline & Floor max slope $\left(^{\circ}\right)$ & 27.8 & 24.7 & 24.6 & 24.3 & 25.0 & 35.4 & 25.4 & 29.4 & 22.9 & 23.2 & 26.7 & 28.7 & 22.9 & 26.5 & 35.4 \\
\hline \multirow{4}{*}{ 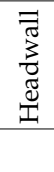 } & Mean slope $\left(^{\circ}\right)$ & 26.1 & 28.0 & 25.3 & 22.7 & 23.0 & 28.4 & 33.8 & 33.4 & 25.4 & 34.4 & 22.0 & 30.7 & 22.0 & 27.8 & 34.4 \\
\hline & Profile closure $\left({ }^{\circ}\right)$ & 37.1 & 45.4 & 73.0 & 79.5 & 70.0 & 72.4 & 89.6 & 70.6 & 49.6 & 49.7 & 47.7 & 44.9 & 37.1 & 60.8 & 89.6 \\
\hline & Area $\left(\mathrm{km}^{2}\right)$ & 0.4 & 0.2 & 0.6 & 0.4 & 0.7 & 0.6 & 0.1 & 0.2 & 0.4 & 0.2 & 0.3 & 0.2 & 0.1 & 0.4 & 0.7 \\
\hline & Grade & 4 & 4 & 3 & 3 & 3 & 3 & 3 & 3 & 3 & 3 & 4 & 4 & & & \\
\hline
\end{tabular}


The morphometric values of the main cirques on Jablanica Mt. (Table 1) are comparable to other regions of the world [37], and the main dimensional parameters (area, $\mathrm{L} / \mathrm{W}, \mathrm{L} / \mathrm{H}, \mathrm{W} / \mathrm{H}$ ) are very similar to the cirques from other mountains in the region (e.g., Northern Greece [53,54]; Retezat Mts., Romania [55]). Cirque size, as expected, generally decreases with increase of cirque floor elevation (Figure 7B).

All of the cirques have relatively high plan closure values $\left(>174^{\circ}\right)$, and based on both plan and profile closure, three groups can be delineated: the first group (cirques 1, 2, 8, 8a, 9 and 10) has high plan closure values, but relatively low profile closure values; the second group (cirques 3, 5, 7) has high profile closure values but relatively lower plan closure values; and the third group (cirques 4 , 6 and 6a) has highest values for both plan and profile closure which might reflect higher degree of development (Figure 7C).

The length (L) of the main cirques averages at $838 \mathrm{~m}$, the width (W) averages $806 \mathrm{~m}$ and the height $(\mathrm{H})$ averages $288 \mathrm{~m}$. Power exponents of logarithmic regressions of cirque length, width and height against cirques size indicate that cirque growth was allometric (Figure 7D), with cirques growing faster in horizontal than vertical dimensions. Similar findings have been reported from many regions [37] and have been attributed to periglacial processes and/or headwall recession having higher influence over subglacial deepening [56].

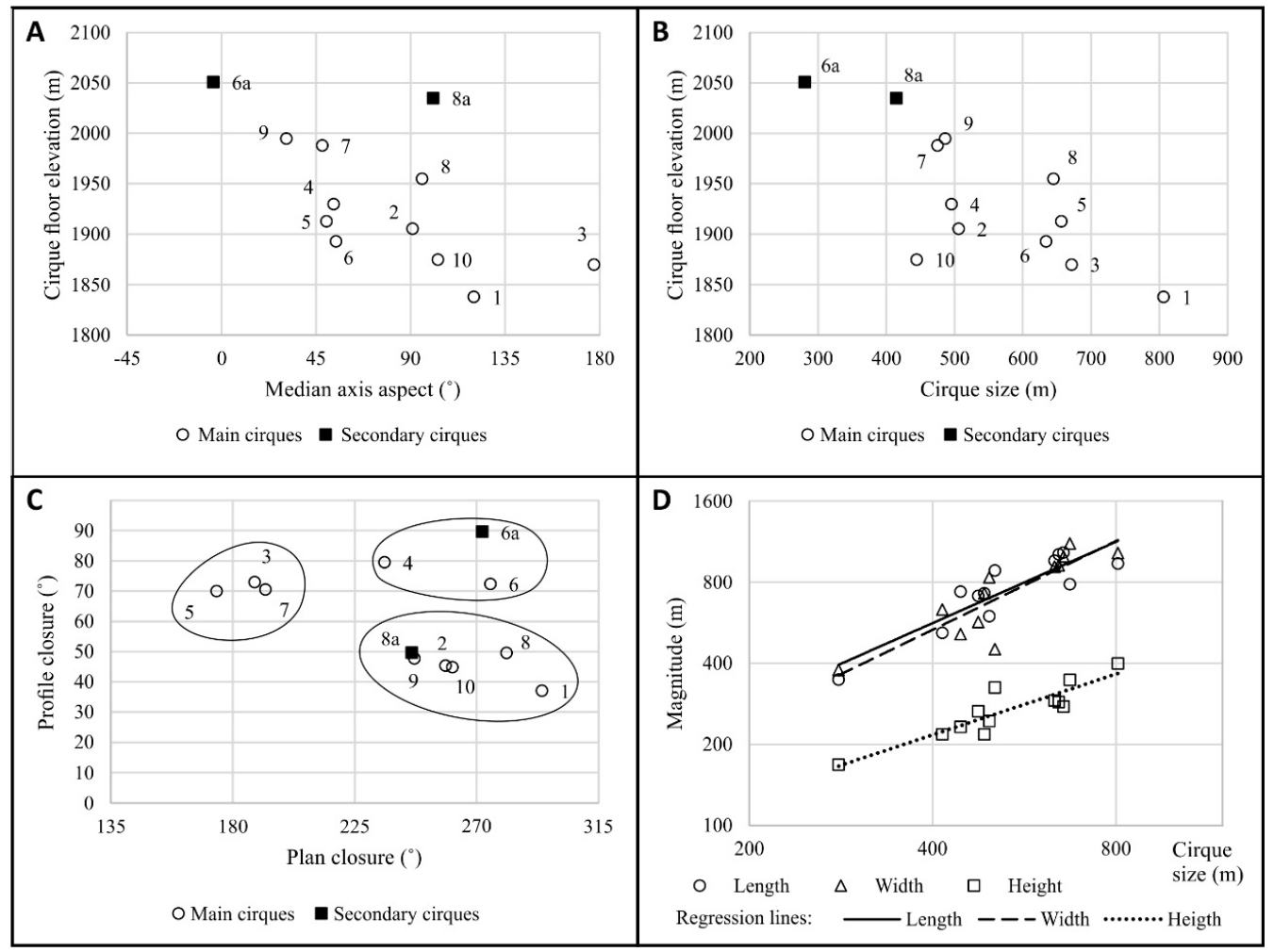

Figure 7. Graphical presentation of some morphometric characteristics of the cirques on Jablanica Mt.: Changes of cirque median axis aspect (A) and size (B) with cirque floor elevations; (C) Cirque plan closure vs. profile closure; (D) Allometric plots of cirque size $(\sqrt[3]{\mathrm{L} \times \mathrm{W} \times \mathrm{H}})$ vs. cirque length, width and height $\left(\mathrm{L}\right.$ exponent $=1.00, \mathrm{r}^{2}=0.79,95 \%$ conf. int. $=0.64-1.34 ; \mathrm{W}$ exponent $=1.09, \mathrm{r}^{2}=0.75$, $95 \%$ conf. int. $=0.65-1.54 ; \mathrm{H}$ exponent $=0.75, \mathrm{r}^{2}=0.80,95 \%$ conf. int. $\left.=0.49-1.01\right)$.

Although all of the cirques have at least some of the textbook attributes of a glacial cirque (e.g., generally high plan and profile closure), most of them have some attributes that are not so well developed or are lacking (e.g., threshold and poorly developed floor). Six primary $(3,4,5,6,7$ and 8) and the two secondary (6a and 8a) cirques are classified as "definite" cirques, three of which $(5,6,8)$ 
also have glacial lakes. They have the morphology of a well-developed cirque, supported by higher values for plan and profile closure, but some are lacking threshold (e.g., cirques 3,7 ) or have somewhat lower values for profile (e.g., cirques 8,8 a) or plan closure (e.g., cirques $3,5,7)$. The other four primary cirques $(1,2,9,10)$ are classified as "poor" cirques, because they generally have lower profile (although high plan) closure values, poorly developed floor and are lacking a well-developed threshold.

\subsection{Glacier Reconstruction}

The cirque boundaries are well defined, and the valleys are steep and glacially shaped with several glacial steps, and thresholds. Most of the ridges above $1900 \mathrm{~m}$ a.s.l. exhibit a smoothed morphology (Figure 4A), probably reflecting the presence of a former icefield. Accordingly, we suggest that glaciers of the reconstructed maximum ice extent (rMIE) likely originated in a large icefield covering most of the area above $1900 \mathrm{~m}$ a.s.l. elevation (Figure 8). The largest glaciers reached the foothills but did not extend to the piedmont. During our research no evidence was found of the existence of a previously suggested $[5,6]$ larger glacier phase, with ice lobes extending down to $700-750 \mathrm{~m}$ a.s.l.

Glacier reconstruction of the rMIE glaciers (Vevčani Member/phase) suggests that the glaciers occupied an area of $22.6 \mathrm{~km}^{2}$ within the studied middle part of Jablanica Mt. The longest glacier was in the Labuništa system with a length of $7.2 \mathrm{~km}$ (Figure 8).

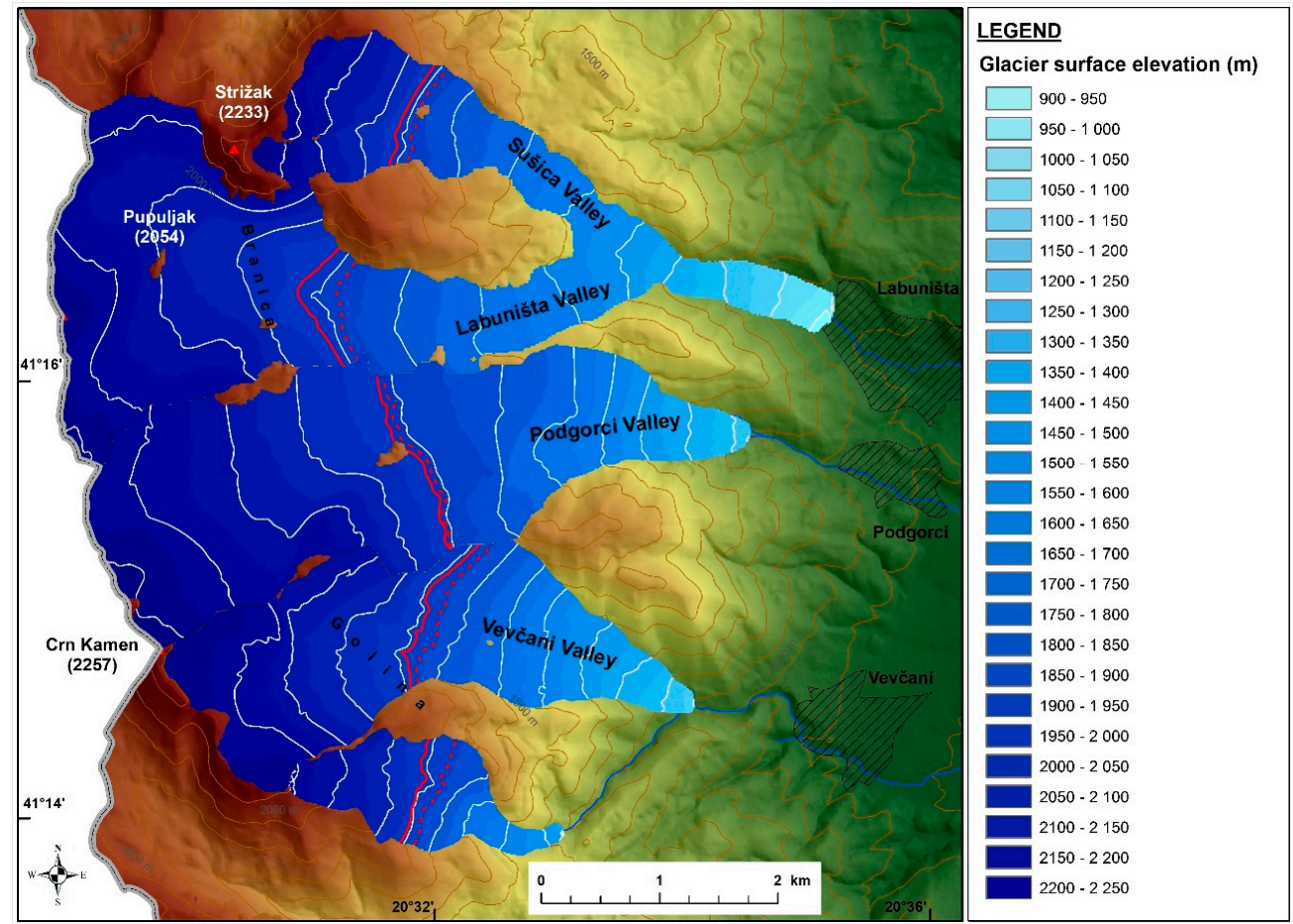

Figure 8. Reconstructed glaciers during Vevčani phase in the Jablanica Mt. Solid red line indicates the size-specific Accumulation Area Ratio (ssAAR) equilibrium-line altitude (ELA), dashed red line indicates the Area-Altitude Balance Ratio (AABR) ELA.

The ice thickness reached its maximum values $(200 \mathrm{~m})$ in the cirque and middle part of the Podgorci and Labuništa valleys (Figure 9). In the lower reach of the Vevčani Valley the thickness of the reconstructed glacier is small (down to zero). This may be an artefact of the reconstruction, as the lateral moraines outlined by the spots of thinned glaciers were not yet filling the valley during this phase. 


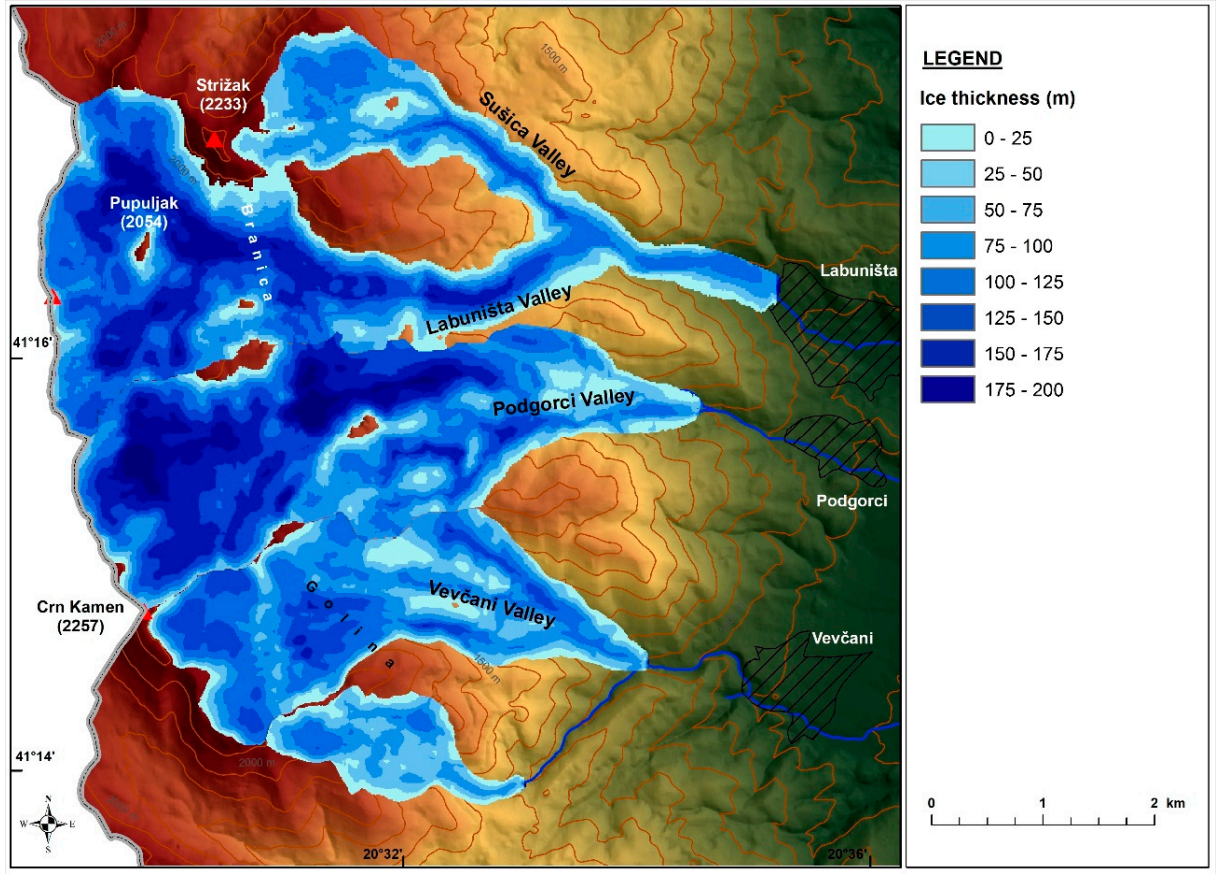

Figure 9. Ice thickness of the reconstructed glaciers during Vevčani phase in the Jablanica Mt.

The estimated ELAs during this phase varied between $1786 \mathrm{~m}$ and $1819 \mathrm{~m}$ a.s.l. if calculated by the ssAAR method and between $1756 \mathrm{~m}$ and $1809 \mathrm{~m}$ by the AABR method. The average values are $1809 \mathrm{~m}$ and $1777 \mathrm{~m}$, respectively (Table 2; Figure 8).

Table 2. Results from the glacial reconstruction of the Vevčani phase (reconstructed maximum ice extent (rMIE)) on Jablanica Mt.

\begin{tabular}{cccccc}
\hline Glacial Systems & Length $(\mathbf{m})$ & Area $\left.\mathbf{( k m}^{\mathbf{2}}\right)$ & ssAAR $_{\mathbf{0}}$ & ssAAR ELA $(\mathbf{m})$ & AABR ELA $(\mathbf{m})$ \\
\hline Labuništa & 7.15 & 9.32 & 0.628 & 1819 & 1782 \\
Podgorci & 6.08 & 7.36 & 0.612 & 1817 & 1809 \\
Vevčani-main & 4.58 & 4.65 & 0.583 & 1786 & 1756 \\
Vevčani-south tributary & 2.49 & 1.28 & 0.499 & 1814 & 1762 \\
Min. & 2.5 & 1.3 & 0.50 & 1786 & 1756 \\
Max. & 7.2 & 9.3 & 0.63 & 1819 & 1809 \\
Mean & 5.1 & 5.7 & 0.58 & 1809 & 1777 \\
\hline
\end{tabular}

\section{Discussion}

The glacial landforms mapped on the eastern side of the Jablanica Mt. supported the distinction of six deglaciation phases. Cirque morphometry parameters of the studied ten primary and two secondary cirques suggest that majority of the cirques are not "well-defined" but fall in the "definite" or "poor" classes [41].

The mapped glacier morphology suggest that subglacial deepening was limited within the cirques and was more intensive in the valley sections during more extensive glacial phases. The lack of developed cirque thresholds and poorly developed cirque floors suggest that cirque glaciers existed for a relatively short period or they were not erosive enough to create well-developed cirques [37].

For a tentative estimate of the timing of the maximum glacial advance, the ELAs of the reconstructed glaciers in the Jablanica Mt. were compared to ELAs calculated for surrounding mountain ranges of the Balkan Peninsula where geochronological data (or at least age estimates) are available (Figure 10). The timing of the maximum ice extent varied between the LGM (Šar, Rila, Retezat Mts.), the MIS 6 (Prokletije Mt.) and MIS 12 (Orjen, Durmitor, Pindus Mts.) phases in the 
region, therefore the ELAs calculated for Vevčani phase were compared to these datasets. Diverse calculation methods were used by the cited studies, which may increase the scatter of the ELAs of the literature data, however to a first order this approach is still valid for putting the results of this study in a regional context.

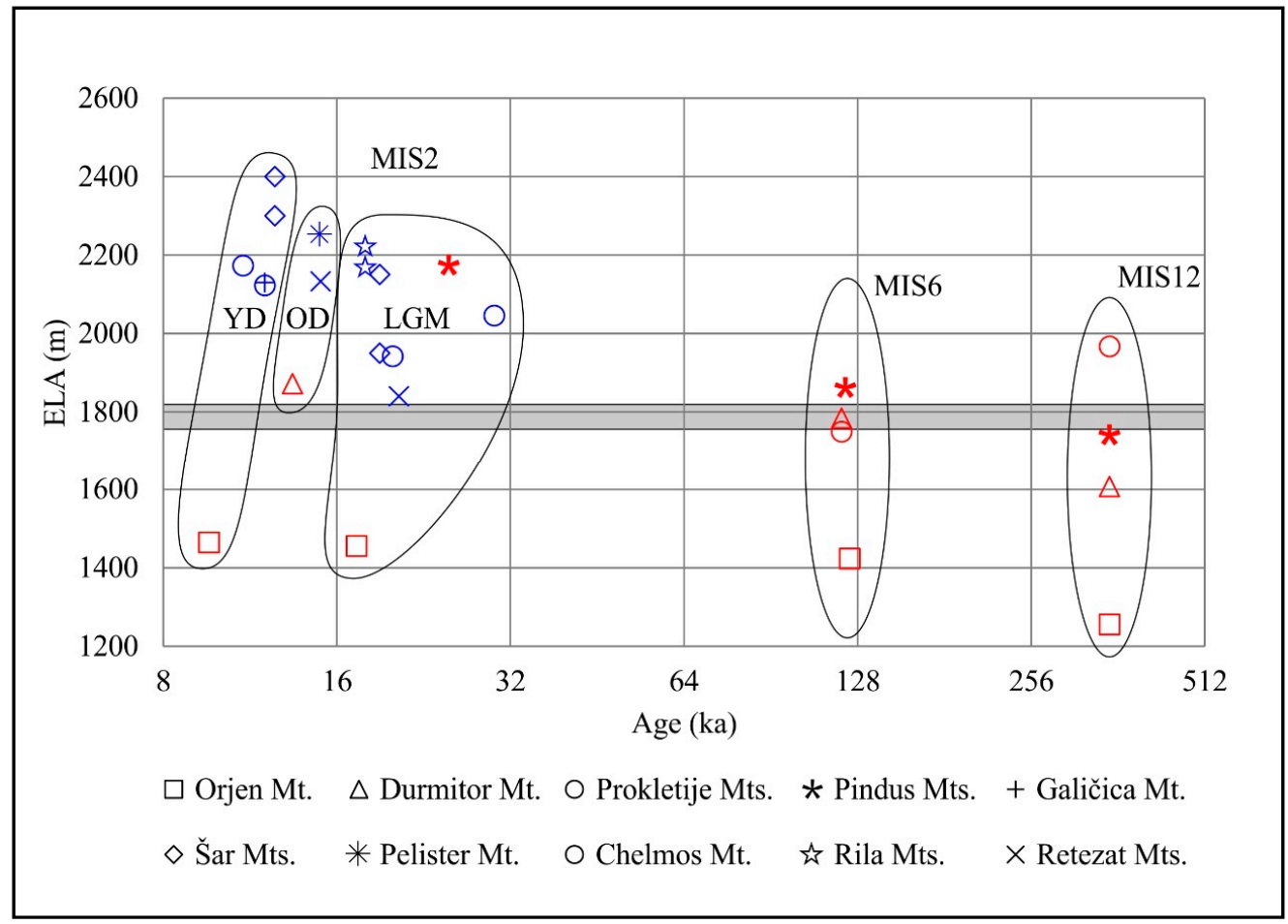

Figure 10. Elevations of ELAs and their assigned ages from mountain ranges in the region and the range of rMIE ELA values from Jablanica Mt. (shaded area). Red symbols represent minimum ages. Age scale is logarithmic. For location of discussed mountains refer to Figure 1. Sources: Orjen Mt. [10]; Durmitor Mts. [11]; Prokletije Mts. [57]; Pindus Mts. [54]; Galičica Mt. [19]; Šar Mts. [14]; Pelister Mt. [16]; Chelmos Mt. [18]; Rila Mts. [15]; Retezat Mts. [58].

First the ELAs reported for the LGM were considered, which were reported for the Olympus [12], Pindus [54], Orjen [10], Durmitor [11], Prokletije [57], Šar, [14] and Rila [15] mountains. The previously published ELAs for the LGM in the region were between $1456 \mathrm{~m}$ and $2222 \mathrm{~m}$ a.s.l. The lowest value was reported in the Orjen Mt., which, like today, probably received extreme amount of precipitation due to its coastal setting. Among the inner ranges of the Balkan Peninsula the ELA of the Durmitor Mt. was the second lowest with $1872 \mathrm{~m}$. For a comparison, the LGM ELA in the northern valleys of the Retezat Mts., Southern Carpathians ( $~ 500 \mathrm{~km}$ to the NNE, at a more continental setting) was at $\sim 1840$ m a.s.1. [58,59].

Glaciations during the MIS 6 were reported in the Durmitor, Pindus and Prokletije ranges of similar geographical setting as the Jablanica Mt., with values between 1750 and 1862 m. For coastal ranges of the Orjen and the Olympus Mts. lower values were reported (1424 and $1000 \mathrm{~m}$, respectively), indicating depressed ELA at the coastal setting. At the Durmitor, Pindus and Orjen Mts. the moraines of the maximum glaciation were dated as $>350 \mathrm{ka}$ and were linked to the MIS 12. Their ELAs were $1607 \mathrm{~m}, 1740 \mathrm{~m}$ and $1256 \mathrm{~m}$, respectively.

The ELA values estimated at $\sim 1800 \mathrm{~m}$ for the Jablanica Mt. are most similar to the ELAs reported for the MIS 6 glacial stage in the inner ranges of the Balkan Peninsula (Figures 1A and 10), which may be a preliminary age estimate for the maximum ice extent in the Jablanica Mt. 


\section{Conclusions}

Mapping of glacial landforms and deposits offered the opportunity for the first reconstruction of the Pleistocene glaciers of the Jablanica Mt. using state-of-art GIS supported tools. A revised glacio-geomorphological map was produced with six members of the Jablanica Glacial Formation identified based on morphostratigraphical criteria.

The morphometric analysis of the cirques showed that most of the cirques on Jablanica Mt., although having at least some of the textbook attributes of a glacial cirque, are not well developed. The wide and open cirques together with deep and stepped glacial valleys with several thresholds suggest that glacial erosion during the most extended glacial phases was focused along the valley axis to a position closer to the former ELA. The development stage of the cirques may also reflect more dynamic glaciers in the deeper, better developed cirques and less dynamic and/or shorter-lived glaciers in the poorly developed cirques.

The glacier reconstruction suggests that glaciers during the maximum ice extent formed an icefield covering most of the range above $1900 \mathrm{~m}$ a.s.l. elevation. The glacier cover for this largest stage could be estimated to $22.6 \mathrm{~km}^{2}$ with an ELA around $1800 \mathrm{~m}$ a.s.l. in the studied valleys of central Jablanica Mt. The existence of a former icefield with several glacier tongues in the valleys is in agreement with results of the morphometric analysis suggesting enhanced glacial erosion along valley axes.

The timing of these former glacial stages remains an open question. However, the revised glacio-geomorphological map and the comparison of the calculated ELA with published ELA data of the region, tentatively assigns the maximum ice extent of the Jablanica Mt. to MIS 6. The presented geomorphological map and glacier reconstruction will serve as a valuable foundation for future efforts to establish a glacial chronological framework on Jablanica Mt.

Author Contributions: Conceptualization, M.T., Z.K. and Z.R.-R.; Funding acquisition, Z.R.-R.; Investigation, M.T., B.M., Z.K., I.M. and Z.R.-R.; Project administration, Z.R.-R.; Resources, M.T.; Software, B.M.; Visualization, M.T. and B.M.; Writing—original draft, M.T. and Z.R.-R.; Writing—review \& editing, B.M., Z.K. and I.M.

Funding: This research was funded by the National Research, Development and Innovation Office of Hungary grant OTKA FK-124807 and by the European Union and the State of Hungary, co-financed by the European Regional Development Fund in the project of GINOP-2.3.2-15-2016-00009 'ICER'.

Acknowledgments: The authors acknowledge the two anonymous reviewers for their constructive comments which helped to improve the paper.

Conflicts of Interest: The authors declare no conflict of interest.

\section{References}

1. Knight, P.G. (Ed.) Glacier Science and Environmental Change; John Wiley \& Sons: Hoboken, NJ, USA, 2008; ISBN 978-1-405-10018-2.

2. Kuhlemann, J.; Rohling, E.J.; Krumrei, I.; Kubik, P.; Ivy-Ochs, S.; Kucera, M. Regional Synthesis of Mediterranean Atmospheric Circulation During the Last Glacial Maximum. Science 2008, 321, 1338-1340. [CrossRef] [PubMed]

3. Carr, S.J.; Lukas, S.; Mills, S.C. Glacier reconstruction and mass-balance modelling as a geomorphic and palaeoclimatic tool. Earth Surf. Process. Landf. 2010, 35, 1103-1115. [CrossRef]

4. Cvijić, J. Das Rilagebirge und seine ehemalige Vergletscherung. Z. Ges. Erdkd. Berl. 1898, 33, $200-253$. (In German)

5. Cvijić, J. L'époque glaciaire dans la péninsule des Balkans. Ann. Géogr. 1917, 141, 189-218. (In French) [CrossRef]

6. Dedijer, J. Traces glaciaires en Albanie et en Nouvelle Serbie. Géogr. Bull. Soc. Géogr. 1917, 31, $325-337$. (In French)

7. Messerli, B. Die eiszeitliche und die gegenwartige Vertgletscherung im Mittelemeeraum. Geogr. Helv. 1967, 22, 105-228. (In German) [CrossRef] 
8. Hughes, P.D.; Woodward, J.C. Quaternary Glaciation in the Mediterranean Mountains: A new synthesis. In Quaternary Glaciation in the Mediterranean Mountains; Hughes, P.D., Woodward, J.C., Eds.; Special Publications 433; Geological Society: London, UK, 2016; pp. 1-23.

9. Hughes, P.D.; Woodward, J.C.; Gibbard, P.L.; Macklin, M.G.; Gilmour, M.A.; Smith, G.R. The glacial history of the Pindus mountains, Greece. J. Geol. 2006, 114, 413-434. [CrossRef]

10. Hughes, P.D.; Woodward, J.C.; van Calsteren, P.C.; Thomas, L.E.; Adamson, K. Pleistocene ice caps on the coastal mountains of the Adriatic Sea: Palaeoclimatic and wider palaeoenvironmental implications. Quat. Sci. Rev. 2010, 29, 3690-3708. [CrossRef]

11. Hughes, P.D.; Woodward, J.C.; van Calsteren, P.C.; Thomas, L.E. The glacial history of the Dinaric Alps, Montenegro. Quat. Sci. Rev. 2011, 30, 3393-3412. [CrossRef]

12. Smith, G.W.; Nance, R.D.; Genes, A.N. Pleistocene glacial history of Mount Olympus, Greece: Neotectonic uplift, equilibrium line elevations, and implications for climatic change. In Postcollisional Tectonics and Magmatism in the Mediterranean Region and Asia; Dilek, Y., Pavlides, S., Eds.; Special Paper 409; Geological Society of America: Boulder, CO, USA, 2006; pp. 157-174.

13. Woodward, J.C.; Macklin, M.G.; Smith, G.R. Pleistocene glaciation in the mountains of Greece. In Quaternary Glaciations-Extent and Chronology. Part I; Ehlers, J., Gibbard, P.L., Eds.; Elsevier Science: New York, NY, USA, 2004; pp. 155-173.

14. Kuhlemann, J.; Milivojevic, M.; Krumrei, I.; Kubik, P.W. Last glaciation of the Šara range (Balkan peninsula): Increasing dryness from the LGM to the Holocene. Austrian J. Earth Sci. 2009, 102, 146-158.

15. Kuhlemann, J.; Gachev, E.; Gikov, A.; Nedkov, S.; Krumrei, I.; Kubik, P. Glaciation in the Rila mountains (Bulgaria) during the Last Glacial Maximum. Quat. Int. 2013, 293, 51-62. [CrossRef]

16. Ribolini, A.; Bini, M.; Isola, I.; Spagnolo, M.; Zanchetta, G.; Pellitero, R.; Mechernich, S.; Gromig, R.; Dunai, T.J.; Wagner, B.; et al. An Oldest Dryas glacier expansion on Mount Pelister (Former Yugoslavian Republic of Macedonia) according to ${ }^{10}$ Be cosmogenic dating. J. Geol. Soc. Lond. 2017, 175, 100-110. [CrossRef]

17. Smith, G.W.; Nance, R.D.; Genes, A.N. Quaternary Glacial History of Mount Olympus. Geol. Soc. Am. Bull. 1997, 109, 809-824. [CrossRef]

18. Pope, R.J.; Hughes, P.D.; Skoutsos, E. Glacial history of Mt Chelmos, Peloponnesus, Greece. In Quaternary Glaciation in the Mediterranean Mountains; Hughes, P.D., Woodward, J.C., Eds.; Special Publications 433; Geological Society: London, UK, 2017; pp. 211-236.

19. Gromig, R.; Mechernich, S.; Ribolini, A.; Wagner, B.; Zanchetta, G.; Isola, I.; Bini, M.; Dunai, T. Evidence for a Younger Dryas deglaciation in the Galicica Mountains (FYROM) from cosmogenic 36Cl. Quat. Int. 2018, 464, 352-363. [CrossRef]

20. Marjanac, T.; Marjanac, L. The extent of middle Pleistocene ice cap in the coastal Dinaric Mountains of Croatia. Quat. Res. 2016, 85, 445-455. [CrossRef]

21. Velić, J.; Velić, I.; Kljajo, D.; Protrka, K.; Škrabić, H.; Špoljar, Z. A geological overview of glacial accumulation and erosional occurrences on the Velebit and the Biokovo Mts., Croatia. Min. Geol. Pet. Eng. Bull. 2017, 32, 77-96. [CrossRef]

22. Gachev, E.; Stoyanov, K.; Gikov, A. Small glaciers on the Balkan Peninsula: State and changes in the last several years. Quat. Int. 2016, 415, 33-54. [CrossRef]

23. Hughes, P.D. Twenty-first Century Glaciers and Climate in the Prokletije Mountains, Albania. Arct. Antarct Alp. Res. 2009, 41, 455-459. [CrossRef]

24. Ruszkiczay-Rüdiger, Z.; Temovski, M.; Madarász, B.; Milevski, I.; Braucher, R.; Kern, Z. Glacial landforms and deglaciation stages in the Jablanica Mountain, Macedonia, Central Balkan Peninsula. Geophys. Res. Abstr. 2018, 20, EGU2018-1573.

25. Kolčakovski, D. Morfogenetski Procesi i Nivnite Reljefni Formi na Visokoplaninskite Predeli na Planinite Jablanica, Stogovo, Stara Galičica i Pelister (Morphogenetical Processes and Their Relief Forms on the High Mountain Regions on the Mountains Jablanica, Stogovo, Stara Galičica and Pelister). Ph.D. Thesis, Ss. Cyril and Methodius University, Skopje, Macedonia, 1996. (In Macedonian)

26. Dumurdžanov, N.; Serafimovski, T.; Burchfiel, B.C. Cenozoic tectonics of Macedonia and its relation to the South Balkan extensional regime. Geosphere 2005, 1, 1-22. [CrossRef]

27. Burchfiel, B.C.; Nakov, R.; Dumurdžanov, N.; Papanikolaou, D.; Tzankov, T.; Serafimovski, T.; King, R.W.; Kotzev, V.; Todosov, A.; Nurce, B. Evolution and dynamics of the Cenozoic tectonics of the South Balkan extensional system. Geosphere 2008, 4, 919-938. [CrossRef] 
28. Lindhorst, K.; Krastel, S.; Reicherter, K.; Stipp, M.; Wagner, B.; Schwenk, T. Sedimentary and tectonic evolution of Lake Ohrid (Macedonia/Albania). Basin Res. 2015, 27, 84-101. [CrossRef]

29. Dumurdžanov, N.; Serafimovski, T.; Burchfiel, B.C. Evolution of the Neogene-Pleistocene basins of Macedonia. Geol. Soc. Am. Digit. Map. Chart. Ser. 2004, 1, 1-20.

30. Dumurdžanov, N.; Ivanovski, T. Explanatory Notes for the General Geological Map of Ohrid and Podgradec, 1:100000; Federal Geological Survey: Belgrade, Serbia, 1978; p. 51. (In Macedonian)

31. Klimaszewski, M. Uslovite vo pleistocenskata glacijacija na planinite vo SR Makedonija (The conditions of Pleistocene glaciation on the mountains in SR Macedonia). Geogr. Razgl. 1978, 15-16, 13-27. (In Macedonian)

32. Klimaszewski, M. Warunki plejstocen skiego zlodowacenia gór Republiki Macedonii (Conditions of the Pleistocen glaciation of Macedonia mountains). Prz. Geogr. 1994, 66, 309-325. (In Polish)

33. Fick, S.; Hijmans, R. WorldClim 2: New 1-km spatial resolution climate surfaces for global land areas. Int. J. Climatol. 2017, 37, 4302-4315. [CrossRef]

34. Bechtel, B. A new global climatology of annual land surface temperature. Remote Sens. 2015, 7, $2850-2870$. [CrossRef]

35. Toporaphic Maps in 1:25000 Scale; Ohrid 1-1 to Ohrid 4-4 sheets; Vojnogeografski Institute: Belgrade, Serbia, 1973.

36. Milevski, I.; Gorin, S.; Markoski, M.; Radevski, I. Comparison of Accuracy of DEM's Available for the Republic of Macedonia. In Proceedings of the 3rd International Geographic Symposium—GEOMED 2013; Efe, R., Atalay, I., Curebal, I., Eds.; Dokuz Eylul University: Antalya, Turkey, 2013; pp. 165-172.

37. Barr, I.D.; Spagnolo, M. Glacial cirques as palaeoenvironmental indicators: Their potential and limitations. Earth Sci. Rev. 2015, 151, 48-78. [CrossRef]

38. Hughes, P.D.; Gibbard, P.L.; Woodward, J.C. Quaternary glacial records in mountain regions: A Formal stratigraphical approach. Episodes 2005, 28, 85-92.

39. Mîndrescu, M.; Evans, I.S. Cirque form and development in Romania: Allometry and the buzzsaw hypothesis. Geomorphology 2014, 208, 117-136. [CrossRef]

40. Evans, I.S. Allometric development of glacial cirque form: Geological, relief and regional effects on the cirques of Wales. Geomorphology 2006, 80, 245-266. [CrossRef]

41. Evans, I.S.; Cox, N.J. The form of glacial cirques in the English Lake District, Cumbria. Z. Geomorphol. 1995, 39, 175-202.

42. Pellitero, R.; Rea, B.R.; Spagnolo, M.; Bakke, J.; Ivy-Oches, S.; Frew, C.R.; Hughes, P.; Ribolini, A.; Lukas, S.; Renssen, H. GlaRe, a GIS tool to reconstruct the 3D surface of paleoglaciers. Comput. Geosci. 2016, 94, 77-85. [CrossRef]

43. Nye, J.F. The mechanics of glacier flow. J. Glaciol. 1952, 2, 82-93. [CrossRef]

44. Weertman, J. Shear stress at the base of a rigidly rotating cirque glacier. J. Glaciol. 1971, 10, 31-37. [CrossRef]

45. Vieira, G. Combined numerical and geomorphological reconstruction of the Serra da Estrela plateau icefield, Portugal. Geomorphology 2008, 97, 190-207. [CrossRef]

46. Cogley, J.G.; Hock, R.; Rasmussen, L.A.; Arendt, A.A.; Bauder, A.; Braithwaite, R.J.; Jansson, P.; Kaser, G.; Möller, M.; Nicholson, L.; et al. Glossary of Glacier Mass Balance and Related Terms; IHP-VII Technical Documents in Hydrology No. 86, IACS Contribution No. 2; UNESCO-IHP: Paris, France, 2011.

47. Kerschner, H.; Ivy-Ochs, S.; Schlüchter, C. Paleoclimatic interpretation of the early late-glacial glacier in the Gschnitz valley, Central Alps, Austria. Ann. Glaciol. 1999, 28, 135-140. [CrossRef]

48. Pellitero, R.; Rea, B.R.; Spagnolo, M.; Bakke, J.; Hughes, P.; Ivy-Oches, S.; Lukas, S.; Ribolini, A. A GIS tool for automatic calculation of glacier equilibrium-line altitudes. Comput. Geosci. 2015, 82, 55-62. [CrossRef]

49. Kern, Z.; László, P. Size specific steady-state accumulation-area ratio: An improvement for equilibrium-line estimation of small paleoglaciers. Quart. Sci. Rev. 2010, 29, 2781-2787. [CrossRef]

50. Furbish, D.J.; Andrews, J.T. The use of hypsometry to indicate long-term stability and response of valley glaciers to changes in mass transfer. J. Glaciol. 1984, 30, 199-211. [CrossRef]

51. Benn, D.I.; Lehmkuhl, F. Mass balance and equilibrium-line altitudes of glaciers in high-mountain environments. Quat. Int. 2000, 65, 15-29. [CrossRef]

52. Rea, B. Defining modern day Area-Altitude Balance Ratios (AABRs) and their use in glacier-climate reconstructions. Quat. Sci. Rev. 2009, 28, 237-248. [CrossRef]

53. Bathrellos, G.D.; Skilodimou, H.D.; Maroukian, H. The spatial distribution of Middle and Late Pleistocene cirques in Greece. Geogr. Ann. Ser. A Phys. Geogr. 2014, 96, 323-338. [CrossRef] 
54. Hughes, P.D.; Gibbard, P.L.; Woodward, J.C. Geological controls on Pleistocene glaciation and cirque form in Greece. Geomorphology 2007, 88, 242-253. [CrossRef]

55. Urdea, P. Glacial relief and Pleistocene glaciation in Retezat mountains (Transylvanians Alps, Romania). Geogr. Pannon. 2001, 5, 4-7. [CrossRef]

56. Delmas, M.; Gunnell, Y.; Calvet, M. A critical appraisal of allometric growth among alpine cirques based on multivariate statistics and spatial analysis. Geomorphology 2015, 228, 637-652. [CrossRef]

57. Milivojević, M.; Menković, L.; Ćalić, J. Pleistocene glacial relief of the central part of Mt. Prokletije (Albanian Alps). Quat. Int. 2008, 190, 112-122. [CrossRef]

58. Ruszkiczay-Rüdiger, Z.; Kern, Z.; Urdea, P.; Braucher, R.; Madarász, B.; Schimmelpfennig, I. Revised deglaciation history of the Pietrele-Stânişoara glacial complex, Retezat Mts, Southern Carpathians, Romania. Quat. Int. 2016, 415, 216-229. [CrossRef]

59. Ruszkiczay-Rüdiger, Z.; Madarász, B.; Kern, Z.; Urdea, P.; Braucher, R. ASTER Team Late Pleistocene deglaciation and paleo-environment in the Retezat Mountains, Southern Carpathians. Geophys. Res. Abstr. 2017, 19, 2755.

(C) 2018 by the authors. Licensee MDPI, Basel, Switzerland. This article is an open access article distributed under the terms and conditions of the Creative Commons Attribution (CC BY) license (http://creativecommons.org/licenses/by/4.0/). 